\title{
The Growth of Hospitalists and the Future of the Society of General Internal Medicine: Results from the 2014 Membership Survey
}

\author{
Chad S. Miller, $M D^{7}$, Robert L. Fogerty, MD, MPH', Jillian Gann, BA ${ }^{3}$, Christopher P. Bruti, MD ${ }^{4}$, and \\ Robin Klein, $M D^{5}$, The Society of General Internal Medicine Membership Committee \\ Irene Alexandraki, Marilyn Schapira, Jeffrey C. Whittle and Melissa Wei
}

\begin{abstract}
'Department of Internal Medicine, Saint Louis University, St. Louis, MO, USA; ${ }^{2}$ Department of Internal Medicine, Yale School of Medicine, New Haven, CT, USA; ${ }^{3}$ Society of General Internal Medicine, Alexandria, VA, USA; ${ }^{4}$ Department of Internal Medicine, Rush University Medical Center, Chicago, IL, USA; ${ }^{5}$ Department of Medicine, Emory University, Atlanta, GA, USA.
\end{abstract}

According to the most recent annual membership surveys, hospitalists are a rapidly growing component of the Society of General Internal Medicine (SGIM). Should this trend continue, hospitalists could increase from $22 \%$ of SGIM membership in 2014 to nearly $33 \%$ by 2020 . Only $34 \%$ of hospitalists who responded to the survey, however, consider SGIM their academic home, compared to 54\% of non-hospitalist respondents. Based on these survey findings, it is clear that the landscape of general internal medicine is changing with the growth of hospitalists, and SGIM will need to strategize to keep these hospitalist members actively engaged in the organization.

J Gen Intern Med 32(11):1179-85

DOI: $10.1007 / \mathrm{s} 11606-017-4126-7$

(c) Society of General Internal Medicine 2017

\section{INTRODUCTION}

The Society of General Internal Medicine (SGIM) was founded in 1978, and today has more than 3300 members. It's key mission is to lead excellence, change, and innovation in clinical care, education, and research in general internal medicine. ${ }^{1}$

An increasing number of SGIM members self-identify as hospitalists. Since the term was coined 20 years ago, "hospitalist" continues to be one of the fastest-growing medical specialties in both community and academic settings. ${ }^{2,3}$ One estimate suggests that as of 2012, there were more than 28,000 hospitalists in practice in the United States, ${ }^{4}$ and this number has grown to nearly 50,000 in $2017 .^{5}$ By definition, hospital medicine is a location-based specialty, in contrast to traditional organ-based, disease-based, or procedure-based specialties. ${ }^{6}$ Hospitalists play key roles in patient care, resource utilization, quality improvement, and medical education within the hospital setting. Factors contributing to the rapid growth of hospitalists

Electronic supplementary material The online version of this article (doi:10.1007/s11606-017-4126-7) contains supplementary material, which is available to authorized users.

Received February 7, 2017

Revised June 12, 2017

Accepted June 22, 2017

Published online July 25, 2017 include the desire to reduce the cost of inpatient stay, reduce unnecessary utilization of medical resources, provide greater value, and improve efficiency in both the inpatient and outpatient settings. ${ }^{2,},{ }^{3,-8}$ With shared values and goals, remaining connected to the traditional academic roots of general internal medicine is something many hospitalists consider essential. As such, exploration of the current state of hospitalists within SGIM is warranted. Using the 2014 Annual Member Survey, we examined the group of hospitalists within SGIM, including demographics, professional duties, and academic roles.

\section{METHODS}

In the fall of 2014, SGIM conducted a survey of its entire membership. Survey questions were designed and reviewed by the SGIM Membership Committee (see Online Appendix). Previous membership surveys from 2004, 2009, and 2012 were reviewed and questions culled to allow for consistency and comparison. Additional questions were added at the discretion of the SGIM Membership Committee, and were developed by the Membership Committee, other SGIM committees and task forces, and SGIM staff.

The survey comprised 74 questions, including 67 multiplechoice and 7 open-ended items. Content included key epidemiologic characteristics as well as practice setting, support, professional duties, time spent teaching, satisfaction with the society, satisfaction with current job, and value of SGIM membership.

The online survey was distributed directly to members via email as well as through GIM Connect, an online communication platform used for intra-organizational messaging. Out of 3300 members, 1011 completed the survey (response rate of $30.6 \%$ ), which is comparable to prior member surveys. We were unable to directly compare demographic data from the survey to demographic data from SGIM membership records because disclosure of demographic data is optional for SGIM membership, and so the database is incomplete. Members are required, however, to provide contact information, and the society has data on geographic region for every member. We used this as a comparison to determine whether we had a 
Table 1 Comparison of 2014 Annual Survey Respondents by Geographic Region with Membership Distribution

\begin{tabular}{lll}
\hline \hline & $\begin{array}{l}\mathbf{2 0 1 4} \text { Survey } \\
\text { respondents }\end{array}$ & $\begin{array}{l}\mathbf{2 0 1 4} \text { Full } \\
\text { membership }\end{array}$ \\
\hline New England & $16 \%$ & $16 \%$ \\
Mid-Atlantic & $21 \%$ & $21 \%$ \\
Midwest & $21 \%$ & $19 \%$ \\
Southern & $17 \%$ & $18 \%$ \\
Mountain West & $5 \%$ & $4 \%$ \\
Northwest & $6 \%$ & $4 \%$ \\
CA/HI & $10 \%$ & $11 \%$ \\
International & $3 \%$ & $5 \%$ \\
\hline
\end{tabular}

representative sample of the society as a whole. The distribution of the respondents was comparable to the known geographic distribution of the society (Table 1).

Analysis included comparisons between SGIM members who identified as hospitalists and those who did not in order to identify significant differences or trends. A limited number of demographic questions were the same on the 2009, 2012, and the 2014 surveys, and were compared in the analysis. However, cross-tab analysis for respondents who identified as hospitalists could only be performed for the 2012 and 2014 surveys. The 2012 annual survey had a response rate of $33 \%$ and the 2009 survey a response rate of $20 \%$ of total membership.

Statistical significance among the groups of hospitalists and non-hospitalists was calculated with chi-square tests using IBM SPSS software Version 24 (IBM Corp., Armonk, NY). A $p$-value $\leq 0.05$ was determined to indicate statistical significance.

\section{RESULTS}

Among the 1011 respondents to the 2014 survey, 877 identified as either hospitalists or non-hospitalists. Of these, $22 \%$ identified as hospitalists and 78\% as non-hospitalists. In 2012 and $2009,15 \%$ and $11 \%$ of respondents identified as hospitalists, respectively (Fig. 1).

Table 2 lists the results of the demographic data from the survey. Overall, there was no major difference in the percentage of men versus women choosing hospital medicine. Approximately $52 \%$ of hospitalist respondents identified as female, compared to $54 \%$ of non-hospitalist respondents. This is a change from 2012, when only $31 \%$ of the hospitalist respondents were female. Non-hospitalist respondents did not change significantly, as 53\% identified as female in 2012.

Regarding age, the hospitalists are a younger cohort than the non-hospitalists. The majority of hospitalist respondents (73\%) are below the age of 45 , whereas the majority of non-hospitalist respondents (54\%) are 45 years or older. In 2012, 78\% of the hospitalist respondents were below the age of 45 and $50 \%$ of the non-hospitalist respondents were over the age of 45.

The hospitalist respondents are more racially diverse than the non-hospitalists, although this did not meet statistical significance. There are two notable differences regarding race and ethnic background in Table 2. First, a larger percentage of hospitalists (24\%) identify as Asian than do non-hospitalists (15\%). In 2012, $21 \%$ of hospitalists identified as Asian. A larger percentage of non-hospitalists $(72 \%)$ identify as Caucasian/white than do hospitalists (64\%).

The hospitalists have a larger percentage of faculty in the academic ranks of instructor and assistant professor. Approximately $54 \%$ of survey respondents who identified as a hospitalist are at the instructor or assistant professor rank, compared with $39 \%$ of non-hospitalist respondents. Also, $22 \%$ of nonhospitalists are full professors, compared to $11 \%$ of hospitalists. In 2012, $66 \%$ of hospitalist survey respondents

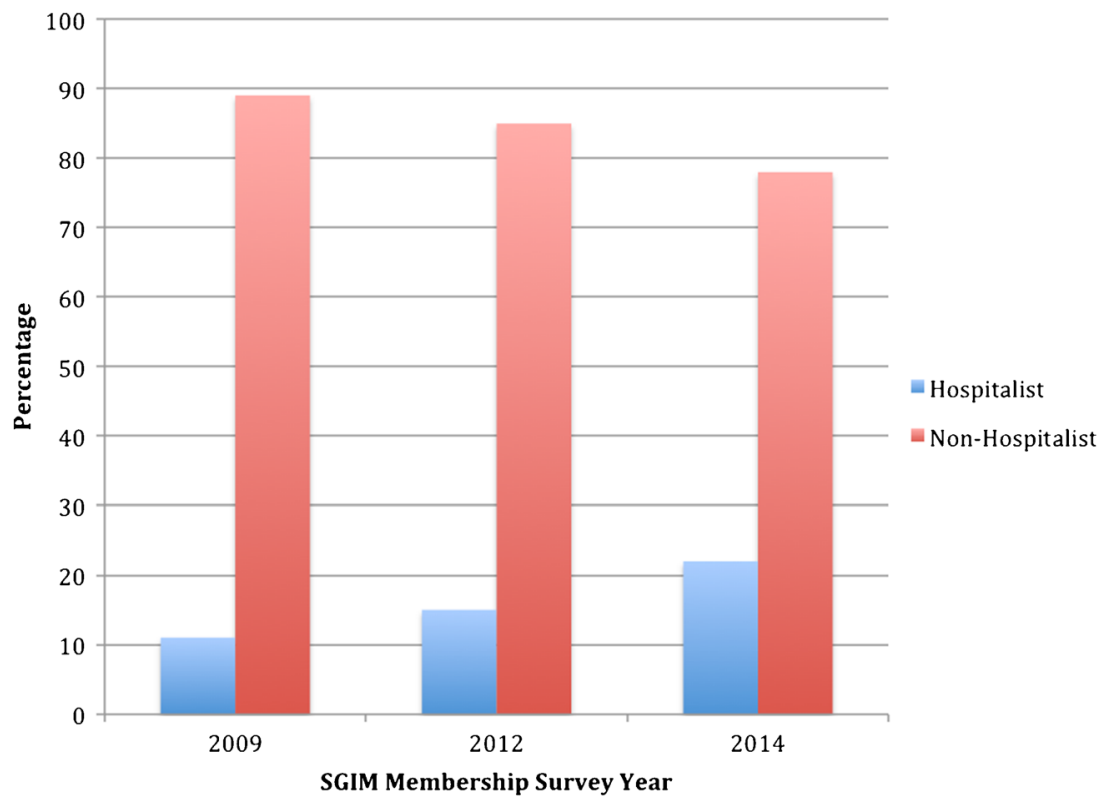

Figure 1 Percentage of hospitalist and non-hospitalist respondents to the SGIM Membership Survey. 
Table 2 Demographic Characteristics and Key Comparisons Between Hospitalist and Non-Hospitalist Survey Respondents

\begin{tabular}{|c|c|c|c|}
\hline & $\begin{array}{l}\text { Hospitalists } \\
n(\%)\end{array}$ & $\begin{array}{l}\text { Non- } \\
\text { hospitalists } \\
n(\%)\end{array}$ & $p$-value \\
\hline \multicolumn{4}{|l|}{ Gender: } \\
\hline Female & $98(52 \%)$ & $373(54 \%)$ & \\
\hline Male & $89(47 \%)$ & $308(45 \%)$ & 0.62 \\
\hline \multicolumn{4}{|l|}{ Age: } \\
\hline $25-44$ years & $138(73 \%)$ & $312(45 \%)$ & \\
\hline $45-64$ years & $47(25 \%)$ & $341(50 \%)$ & \\
\hline$>65$ years & $3(2 \%)$ & $27(4 \%)$ & $<0.001$ \\
\hline \multicolumn{4}{|l|}{ Race/ethnic background: } \\
\hline $\begin{array}{l}\text { African American/ } \\
\text { black }\end{array}$ & $6(3 \%)$ & $34(5 \%)$ & \\
\hline Asian & $46(24 \%)$ & $106(15 \%)$ & \\
\hline Caucasian/white & $125(64 \%)$ & $505(72 \%)$ & \\
\hline Latino/Hispanic & $6(3 \%)$ & $24(3 \%)$ & \\
\hline Native American/ & $0(0 \%)$ & $3(<1 \%)$ & \\
\hline \multicolumn{4}{|l|}{ Alaska Native } \\
\hline Other & $5(3 \%)$ & $15(2 \%)$ & 0.07 \\
\hline \multicolumn{4}{|l|}{ Academic rank: } \\
\hline Instructor & $16(8 \%)$ & $37(5 \%)$ & \\
\hline Clinical or adjunct & $17(9 \%)$ & $42(6 \%)$ & \\
\hline \multicolumn{4}{|l|}{ faculty } \\
\hline Assistant professor & $87(46 \%)$ & $237(34 \%)$ & \\
\hline Associate professor & $37(20 \%)$ & $187(27 \%)$ & \\
\hline Full professor & $21(11 \%)$ & $151(22 \%)$ & \\
\hline $\mathrm{N} / \mathrm{A}$ & $5(3 \%)$ & $19(3 \%)$ & \\
\hline Other & $6(3 \%)$ & $15(2 \%)$ & $<0.001$ \\
\hline \multicolumn{4}{|l|}{ Financial compensation } \\
\hline$<\$ 100,000$ & $5(3 \%)$ & $26(4 \%)$ & \\
\hline$\$ 100,001-150,000$ & $23(12 \%)$ & $82(12 \%)$ & \\
\hline$\$ 150,001-200,000$ & $88(47 \%)$ & $277(42 \%)$ & \\
\hline$\$ 200.001-250,000$ & $39(21 \%)$ & $151(22 \%)$ & \\
\hline$\$ 250,001-300,000$ & $18(9 \%)$ & $62(9 \%)$ & \\
\hline$>\$ 300,000$ & $4(2 \%)$ & $39(6 \%)$ & 0.31 \\
\hline \multicolumn{4}{|c|}{ Principal administrative responsibilities (some chose more than one): } \\
\hline $\mathrm{N} / \mathrm{A}$ & $42(22 \%)$ & $123(18 \%)$ & \\
\hline Dean or associate dean & $7(4 \%)$ & $25(4 \%)$ & \\
\hline Fellowship director & $4(2 \%)$ & $44(6 \%)$ & \\
\hline Clerkship director & $19(10 \%)$ & $48(7 \%)$ & \\
\hline Division/section chief & $24(13 \%)$ & $62(9 \%)$ & \\
\hline $\begin{array}{l}\text { Associate division/ } \\
\text { section chief }\end{array}$ & $8(4 \%)$ & $28(4 \%)$ & \\
\hline Residency program & $7(4 \%)$ & $32(5 \%)$ & \\
\hline director & & & \\
\hline Associate residency & $35(19 \%)$ & $77(11 \%)$ & \\
\hline program director & & & \\
\hline Medical director & $25(13 \%)$ & $79(11 \%)$ & \\
\hline Research center & $3(2 \%)$ & $45(7 \%)$ & \\
\hline \multicolumn{4}{|l|}{ director } \\
\hline Course director & $27(14 \%)$ & $100(15 \%)$ & \\
\hline Chair & $6(3 \%)$ & $15(2 \%)$ & \\
\hline Clinic director & $7(4 \%)$ & $54(8 \%)$ & \\
\hline Hospital administrator & $16(8 \%)$ & $30(4 \%)$ & \\
\hline Other & $27(14 \%)$ & $130(23 \%)$ & $<0.01$ \\
\hline \multicolumn{4}{|c|}{ Proportion of time spent on the following: } \\
\hline \multicolumn{4}{|c|}{ Administrative: } \\
\hline $1-49 \%$ & $139(89 \%)$ & $481(84 \%)$ & \\
\hline $50-99 \%$ & $17(11 \%)$ & $88(15 \%)$ & \\
\hline $100 \%$ & $0(0 \%)$ & $2(<1 \%)$ & 0.22 \\
\hline Clinical: & & & \\
\hline $1-49 \%$ & $97(52 \%)$ & $436(68 \%)$ & \\
\hline $50-99$ & $82(44 \%)$ & $197(31 \%)$ & \\
\hline $100 \%$ & $8(4 \%)$ & $10(1 \%)$ & $<0.001$ \\
\hline Research: & & & \\
\hline $1-49 \%$ & $106(83 \%)$ & $351(91 \%)$ & \\
\hline $50-99$ & $21(17 \%)$ & $31(8 \%)$ & \\
\hline $100 \%$ & $0(0 \%)$ & $2(<1 \%)$ & $<0.05$ \\
\hline Teaching: & & & \\
\hline $1-49 \%$ & $162(92 \%)$ & $601(95 \%)$ & \\
\hline $50-99$ & $14(8 \%)$ & $31(5 \%)$ & \\
\hline $100 \%$ & $1(<1 \%)$ & $2(<1 \%)$ & $<0.26$ \\
\hline Time spent with learner & during clinical & fforts: & \\
\hline $1-49 \%$ & $74(40 \%)$ & $382(62 \%)$ & \\
\hline $50-99$ & $73(40 \%)$ & $157(26 \%)$ & \\
\hline $100 \%$ & $37(20 \%)$ & $74(12 \%)$ & $<0.001$ \\
\hline
\end{tabular}

were instructors or assistant professors, and only $5 \%$ were full professors.

The financial compensation and principal administrative responsibilities are comparable between the two groups, with some exceptions. A larger percentage of non-hospitalists $(6 \%)$ receive a salary greater than $\$ 300,000$ than do hospitalist respondents $(2 \%)$. A larger percentage of hospitalists are clerkship directors, division chiefs, associate residency program directors, and hospital administrators. A larger percentage of the non-hospitalists are fellowship directors, research center directors, and clinic directors.

Academic hospitalists spend their time differently from academic non-hospitalists. A significantly larger percentage of hospitalists spend $50 \%$ or more of their time on clinical activities (44\% vs. $31 \%$ ). Hospitalists also spend more time on research, with $17 \%$ spending more than $50 \%$ of their time on research, compared to less than $9 \%$ of non-hospitalists. Hospitalists are slightly more likely to spend $50 \%$ or more of their time teaching ( $8 \%$ vs. $5 \%$ ), but the majority $(60 \%)$ of hospitalists spend at least $50 \%$ of their clinical time with learners, compared to $38 \%$ of non-hospitalists. Hospitalists and non-hospitalists did not differ significantly in how they spend time on administrative activities.

Table 3 shows significant differences in respondent participation in SGIM and their opinion of the society. The majority $(63 \%)$ of hospitalists who responded to the survey have been SGIM members for less than 5 years. A third of the nonhospitalists have been members for more than 15 years, compared to only $10 \%$ of hospitalist respondents. More nonhospitalists (34\%) consider SGIM membership essential and will "absolutely" renew their membership, compared to hospitalists (19\%). However, the combined percentage of respondents who report SGIM as either essential or very valuable is largely the same among the cohorts (80\% vs. $82 \%$, hospitalist vs. non-hospitalist).

A major finding was that only $34 \%$ of the hospitalists consider SGIM their professional home, compared to $54 \%$ of non-hospitalists. Twenty-one percent of SGIM member hospitalists consider the Society of Hospital Medicine (SHM) their professional home, versus less than $1 \%$ of nonhospitalists. Among all survey respondents, $16 \%$ reported that they were also members of SHM in 2014. This is an increasing trend from 2009 and 2012, when $10 \%$ and $12 \%$ of all survey respondents reported membership in SHM, respectively. In 2009 and 2012, respondents were not asked what organization they considered their professional home.

Membership among hospitalists and non-hospitalists is comparable in organizations such as the American College of Physicians (ACP), Association of Program Directors in Internal Medicine (APDIM), and Clerkship Directors in Internal Medicine (CDIM).

The interest in the annual SGIM meeting favors nonhospitalists. Twenty-five percent of non-hospitalists have attended five or more annual meetings in the past 5 years, compared to $12 \%$ of hospitalist respondents. The number of 
Table 3 Involvement In and Perceived Value of SGIM: Hospitalists and Non-Hospitalists

\begin{tabular}{|c|c|c|c|}
\hline & $\begin{array}{l}\text { Hospitalists, } \\
n(\%)\end{array}$ & $\begin{array}{l}\text { Non- } \\
\text { hospitalists, } n \\
\text { (\%) }\end{array}$ & $p$-value \\
\hline \multicolumn{4}{|c|}{ How long have you been a member of SGIM? } \\
\hline 5 years or less & $119(63 \%)$ & $202(29 \%)$ & \\
\hline $6-10$ years & $39(21 \%)$ & $139(21 \%)$ & \\
\hline $11-15$ years & $12(6 \%)$ & $122(18 \%)$ & \\
\hline$>15$ years & $19(10 \%)$ & $225(33 \%)$ & $<0.001$ \\
\hline \multicolumn{4}{|c|}{ Overall, how valuable is your membership in SGIM? } \\
\hline \multicolumn{4}{|l|}{$\begin{array}{l}\text { absolutely renew each } \\
\text { year }\end{array}$} \\
\hline Very valuable, plan & $113(61 \%)$ & $327(48 \%)$ & \\
\hline $\begin{array}{l}\text { Somewhat valuable, } \\
\text { unsure about renewing }\end{array}$ & $34(18 \%)$ & $115(17 \%)$ & \\
\hline Not valuable, & $2(1 \%)$ & $4(<1 \%)$ & $<0.01$ \\
\hline \multicolumn{4}{|c|}{$\begin{array}{l}\text { unlikely to renew next } \\
\text { year }\end{array}$} \\
\hline \multicolumn{4}{|c|}{$\begin{array}{l}\text { During the last } 5 \text { years, how many national annual SGIM meetings have } \\
\text { you attended? }\end{array}$} \\
\hline 0 & $40(23 \%)$ & $95(15 \%)$ & \\
\hline 1 & $40(23 \%)$ & $100(16 \%)$ & \\
\hline 2 & $30(17 \%)$ & $92(15 \%)$ & \\
\hline 3 & $27(16 \%)$ & $85(14 \%)$ & \\
\hline 4 & $14(8 \%)$ & $97(15 \%)$ & \\
\hline 5 & $21(12 \%)$ & $158(25 \%)$ & $<0.001$ \\
\hline \multicolumn{4}{|c|}{$\begin{array}{l}\text { During the last } 5 \text { years, how many regional meetings have you attended } \\
\text { in your institution's region? }\end{array}$} \\
\hline 0 & $76(45 \%)$ & $253(40 \%)$ & \\
\hline 1 & $24(14 \%)$ & $110(18 \%)$ & \\
\hline 2 & $27(16 \%)$ & $92(15 \%)$ & \\
\hline 3 & $25(15 \%)$ & $61(10 \%)$ & \\
\hline 4 & $10(6 \%)$ & $52(8 \%)$ & \\
\hline 5 & $8(5 \%)$ & $57(9 \%)$ & 0.11 \\
\hline \multicolumn{4}{|c|}{ Please rate your interest in volunteering with SGIM } \\
\hline 1 Not interested & $15(9 \%)$ & $72(12 \%)$ & \\
\hline 2 & $16(10 \%)$ & $64(10 \%)$ & \\
\hline 3 & $47(28 \%)$ & $136(22 \%)$ & \\
\hline 4 & $47(28 \%)$ & $182(30 \%)$ & \\
\hline 5 Extremely & $40(24 \%)$ & $162(26 \%)$ & 0.50 \\
\hline interested & & & \\
\hline \multicolumn{4}{|c|}{$\begin{array}{l}\text { Which of these organizations (if any) do you think of as your } \\
\text { "professional home"? (Select all that apply.) }\end{array}$} \\
\hline Academic Pediatric & $0(0 \%)$ & $0(0 \%)$ & \\
\hline \multicolumn{4}{|l|}{ Association } \\
\hline Academy for Health & $3(1 \%)$ & $8(1 \%)$ & \\
\hline \multicolumn{4}{|l|}{$\begin{array}{l}\text { Services Research } \\
\text { (AcademyHealth) }\end{array}$} \\
\hline $\begin{array}{l}\text { American Academy } \\
\text { of Pharmaceutical }\end{array}$ & $0(0 \%)$ & $0(0 \%)$ & \\
\hline \multicolumn{4}{|l|}{ Physicians } \\
\hline American College of & $49(23 \%)$ & $155(21 \%)$ & \\
\hline \multicolumn{4}{|l|}{ Physicians } \\
\hline American Geriatrics & $1(<1 \%)$ & $13(2 \%)$ & \\
\hline \multicolumn{4}{|l|}{ Society } \\
\hline American Medical & $2(1 \%)$ & $4(<1 \%)$ & \\
\hline Association & & & \\
\hline $\begin{array}{l}\text { Association of } \\
\text { Prooram Directors in }\end{array}$ & $12(6 \%)$ & $35(5 \%)$ & \\
\hline \multicolumn{4}{|l|}{$\begin{array}{l}\text { Program Directors in } \\
\text { Internal Medicine }\end{array}$} \\
\hline Clerkship Directors & $9(4 \%)$ & $16(22 \%)$ & \\
\hline \multicolumn{3}{|l|}{ in Internal Medicine } & \\
\hline Society for Medical & $0(0 \%)$ & $4(<1 \%)$ & \\
\hline \multicolumn{4}{|l|}{ Decision Making } \\
\hline Society of General & $72(34 \%)$ & $397(54 \%)$ & \\
\hline \multicolumn{4}{|l|}{ Internal Medicine } \\
\hline Society of Hospital & $44(21 \%)$ & $3(<1 \%)$ & \\
\hline Medicine & & & \\
\hline Society of Teachers & $2(1 \%)$ & $2(<1 \%)$ & \\
\hline $\begin{array}{l}\text { of Family Medicine } \\
\text { None }\end{array}$ & $11(5 \%)$ & $29(4 \%)$ & \\
\hline
\end{tabular}

(continued on next page)
Table 3. (continued)

\begin{tabular}{|c|c|c|c|}
\hline & $\begin{array}{l}\text { Hospitalists, } \\
n(\%)\end{array}$ & $\begin{array}{l}\text { Non- } \\
\text { hospitalists, } n \\
(\%)\end{array}$ & $p$-value \\
\hline $\begin{array}{l}\text { Other (please } \\
\text { specify) }\end{array}$ & $9(4 \%)$ & $65(9 \%)$ & $<0.001$ \\
\hline \multicolumn{4}{|c|}{ Please rate SGIM's value to you in the following ways: } \\
\hline \multicolumn{4}{|c|}{ Regional and national meetings } \\
\hline Not important & $14(8 \%)$ & $63(9 \%)$ & \\
\hline Important & $95(54 \%)$ & $349(53 \%)$ & \\
\hline Critical & $68(38 \%)$ & $248(38 \%)$ & 0.65 \\
\hline \multicolumn{4}{|c|}{ Continuing medical education (CME) credits } \\
\hline Not important & $65(37 \%)$ & $242(37 \%)$ & \\
\hline Important & $95(54 \%)$ & $354(54 \%)$ & \\
\hline Critical & $15(9 \%)$ & $58(9 \%)$ & 0.99 \\
\hline \multicolumn{4}{|c|}{ Opportunities to present your work } \\
\hline Not important & $17(10 \%)$ & $81(12 \%)$ & \\
\hline Important & $96(54 \%)$ & $351(53 \%)$ & \\
\hline Critical & $65(36 \%)$ & $229(35 \%)$ & 0.60 \\
\hline \multicolumn{4}{|c|}{ Opportunities to publish your work } \\
\hline Not important & $24(14 \%)$ & $123(19 \%)$ & \\
\hline Important & $102(58 \%)$ & $372(57 \%)$ & \\
\hline Critical & $50(28 \%)$ & $157(24 \%)$ & 0.20 \\
\hline \multicolumn{4}{|l|}{ Networking } \\
\hline Not important & $9(5 \%)$ & $31(5 \%)$ & \\
\hline Important & $108(60 \%)$ & $351(52 \%)$ & \\
\hline Critical & $63(35 \%)$ & $285(43 \%)$ & 0.17 \\
\hline \multicolumn{4}{|l|}{ Mentorship } \\
\hline Not important & $39(22 \%)$ & $180(28 \%)$ & \\
\hline Important & $100(57 \%)$ & $344(523)$ & \\
\hline Critical & $37(21 \%)$ & $120(19 \%)$ & 0.30 \\
\hline \multicolumn{4}{|l|}{ National advocacy } \\
\hline Not important & $52(30 \%)$ & $153(23 \%)$ & \\
\hline Important & $101(58 \%)$ & $393(60 \%)$ & \\
\hline Critical & $20(12 \%)$ & $106(16 \%)$ & 0.11 \\
\hline \multicolumn{4}{|c|}{ Providing timely and relevant news and discussion } \\
\hline Not important & $50(28 \%)$ & $143(21 \%)$ & \\
\hline Important & $114(64 \%)$ & $438(67 \%)$ & \\
\hline Critical & $14(8 \%)$ & $77(12 \%)$ & 0.11 \\
\hline \multicolumn{4}{|c|}{ GIM-focused publications } \\
\hline Not important & $29(16 \%)$ & $76(12 \%)$ & \\
\hline Important & $115(64 \%)$ & $432(65 \%)$ & \\
\hline Critical & $36(20 \%)$ & $152(23 \%)$ & 0.22 \\
\hline \multicolumn{4}{|c|}{ Developing clinical skills and knowledge } \\
\hline Not important & $34(19 \%)$ & $173(27 \%)$ & \\
\hline Important & $109(61 \%)$ & $400(61 \%)$ & \\
\hline Critical & $37(20 \%)$ & $79(12 \%)$ & 0.06 \\
\hline \multicolumn{4}{|c|}{ Developing research skills and knowledge } \\
\hline Not important & $39(22 \%)$ & $213(33 \%)$ & \\
\hline Important & $110(63 \%)$ & $354(55 \%)$ & \\
\hline \multirow{2}{*}{\multicolumn{4}{|c|}{ Developing administrative skills and knowledge }} \\
\hline & & & \\
\hline Not important & $53(31 \%)$ & $239(37 \%)$ & \\
\hline Important & $106(62 \%)$ & $339(53 \%)$ & \\
\hline Critical & $13(7 \%)$ & $67(10 \%)$ & 0.10 \\
\hline Job search sources & & & \\
\hline Not important & $102(60 \%)$ & $361(58 \%)$ & \\
\hline Important & $58(34 \%)$ & $230(37 \%)$ & \\
\hline Critical & $9(5 \%)$ & $29(5 \%)$ & 0.85 \\
\hline Career development & ources & & \\
\hline Not important & $54(31 \%)$ & $206(32 \%)$ & \\
\hline Important & $95(55 \%)$ & $365(56 \%)$ & \\
\hline Critical & $24(14 \%)$ & $76(18 \%)$ & 0.75 \\
\hline Opportunities to vol & eer & & \\
\hline Not important & $62(35 \%)$ & $272(43 \%)$ & \\
\hline Important & $95(53 \%)$ & $325(51 \%)$ & \\
\hline Critical & $21(12 \%)$ & $41(6 \%)$ & $<0.05$ \\
\hline $\begin{array}{l}\text { The SGIM Annual Me } \\
\text { gaps }\end{array}$ & ag content redu & my professiona & practice \\
\hline Disagree & $5(4 \%)$ & $22(5 \%)$ & \\
\hline Somewhat disagree & $10(8 \%)$ & $27(6 \%)$ & \\
\hline Neutral & $46(35 \%)$ & $164(36 \%)$ & \\
\hline Somewhat agree & $72(54 \%)$ & $240(53 \%)$ & \\
\hline Agree & $27(17 \%)$ & $140(24 \%)$ & 0.39 \\
\hline
\end{tabular}

regional meetings attended is more comparable between the two groups (Table 3). 
The survey also asked a set of questions that gauged members' interest in volunteering with SGIM as well as their perceived value of certain components of the organization. There was no significant difference between the two groups regarding interest in volunteering, but a larger percentage of non-hospitalists felt that opportunities to volunteer were not important. There was no difference in the perceived value of regional and national meetings, continuing medical education (CME) credits, opportunities for presenting their work, job search sources, or career development resources. Hospitalists, in larger percentages, felt that opportunities to publish their work and developing clinical skills and knowledge were critical. A greater percentage of non-hospitalists felt that networking, national advocacy, and providing timely and relevant news and discussion were critical. More non-hospitalists than hospitalists also felt that developing administrative and research skills were less important.

Hospitalists felt that the SGIM Annual Meeting was less likely to reduce their professional practice gaps, with only $17 \%$ of hospitalists reporting a reduction in practice gaps, compared to $24 \%$ of non-hospitalists. Overall, the difference between the groups on this question was not statistically significant. It should be noted that $45 \%$ of hospitalists agreed somewhat, compared to $40 \%$ of non-hospitalists.

The survey also asked whether SGIM places the correct amount of emphasis on a number of key activities, including regional meetings, national meetings, mentorship, job search, career development, and providing opportunities for publication. The results were comparable between hospitalists and non-hospitalists, with no significant differences.

\section{DISCUSSION}

The overall growth of hospital medicine is reflected in the membership of the Society of General Internal Medicine. If the current trend continues, hospitalists are soon likely to represent a substantial plurality of the SGIM membership, potentially reaching one-third of all members by the year 2020 . With other organizations competing for the interest of hospitalist members, and in view of the changing landscape of general internal medicine, it is crucial for SGIM to retain hospitalist members for the organization to grow. Despite the fact that only $30.6 \%$ of the organization completed the survey, it provides insight into the characteristics of academic hospitalists within SGIM and what they value in the organization. Based on the survey data, hospitalists value SGIM highly, but there are challenges in keeping the hospitalists as connected as other members. From this same data, it is clear that there are plenty of opportunities to increase engagement among hospitalists and to sustain growth. Nonetheless, this will require increased targeting of hospitalists by SGIM and prioritizing needs specific to them.

SGIM has significant loyalty among its members, as evidenced by the large percentage of non-hospitalists that have been members for more than 15 years. However, the membership survey suggests that the most rapidly growing section of membership may have a lower affinity for SGIM. In particular, hospitalists are less likely than non-hospitalists to identify SGIM as a "professional home," and a much smaller percentage of hospitalists consider SGIM essential. Nevertheless, a large majority of hospitalists, $80 \%$, consider SGIM very valuable and will renew their membership. It is unclear whether this enthusiasm gap predicts loss of future hospitalist members or is simply a sign of a different, but stable, relationship.

Another notable difference is that a significant percentage of hospitalists identified SHM as a "professional home." Although 2014 was the first year the professional home question appeared in the survey, the proportion of SGIM members who belong to SHM is growing with the growing number of self-identified hospitalists. The true impact of this phenomenon on the future of SGIM is unclear. Many SGIM members maintain multiple society memberships and continue to stay involved.

It is important to note that $46 \%$ of the non-hospitalist respondents consider another organization their professional home, and this is not a phenomenon exclusive to hospitalist members. These include organizations such as ACP, as well as APDIM and CDIM, which are part of the Alliance for Academic Internal Medicine (AAIM). Future surveys may want to consider the SGIM member's ability to be an active member in multiple organizations simultaneously. It is possible that this phenomenon is natural for generalists, whose clinical and academic responsibilities are often much more heterogeneous than those of our subspecialty colleagues. Furthermore, using the existing SGIMSHM collaborative relationships as a model, there may be opportunities for SGIM to partner with other organizations in a mutually beneficial manner. Nonetheless, SGIM must be able to offer something that is of superior quality or is not available in the other organizations. Otherwise, why incur the costs to maintain the multiple memberships? Knowing who the hospitalists are and what they value in SGIM is imperative.

One of the most significant differences between hospitalist and non-hospitalist respondents is age. Hospitalists tend to be younger and newer members of SGIM. A majority of hospitalist respondents have been members of SGIM for 5 years or less, and a greater percentage of hospitalists are instructors and assistant professors. Because so many hospitalists are at the beginning of their career, SGIM has a tremendous opportunity to focus on career advancement and development of academic skills in this group. In addition, many are just beginning to establish their involvement in SGIM, thus also providing an opportunity for targeted programs to reach out to young hospitalists and encourage them to become involved in SGIM right away.

Notably, the percentage of hospitalist professors responding to the annual survey was larger in 2014 than 2012. In a recently published article by Seymann et al., the authors identified a cohort of successful academic hospitalist programs, which they noted comprised a small number of senior faculty ( $3 \%$ professors) and varied significantly in the amount 
of funded research and scholarship. ${ }^{9}$ The survey suggests the successful retention of a very small group of the most experienced and senior hospitalists, which is a positive development for SGIM, for two key reasons. First, it suggests the continued maturation and sustainability of the academic hospitalist career. This will likely continue to grow. Second, this bodes well for finding appropriate mentorship and leadership within SGIM for the hospitalists who are associate professors, assistant professors, and instructors. Senior leadership will play a key role in growing and sustaining younger hospitalist membership. Because of their value to the organization, the retention and development of senior leaders should be a top priority. The Association of Chiefs and Leaders in General Internal Medicine (ACLGIM) is a tremendous resource with which to engage and develop these future leaders.

SGIM is known for its leadership and research in medical education, which aligns well with the growing group of hospitalists. Our results show an increasing hospitalist influence in medical education and training. Hospitalists spend more of their clinical time with learners than do nonhospitalists. This comes as no surprise, with the heavy emphasis on inpatient training during residency and medical school. Hospitalists also appear to be taking on a larger role in medical education leadership. Hospitalists constitute a greater percentage of clerkship directors and associate program directors than do non-hospitalists. This trend is likely to continue, and may provide an opportunity to promote the educational and leadership opportunities within SGIM directly to hospitalists to align with their current interests and careers.

Hospitalists and non-hospitalists differed in the aspects of SGIM that they valued. First, hospitalists felt that the annual meeting was less effective in reducing their clinical practice gaps. By its nature, SGIM is focused on the tripartite mission of education, research, and clinical work. It is worth considering adding clinical content to the annual meeting, without compromising education and research. Second, hospitalists felt that opportunities to publish their work and develop clinical skills were more essential parts of SGIM than did non-hospitalist respondents. Again, adding more clinical content to the annual meeting may be helpful, but additional expansion of the Journal of General Internal Medicine (JGIM) and its web- and printbased clinical content may be a consideration that fulfills both needs. Finally, it is important to note what is less appealing to hospitalists. They appeared to be less enthusiastic about advocacy, networking, and the provision of timely and relevant news, although no differences were statistically significant.

Finally, we feel it is important to briefly discuss an area of tension between hospitalists and ambulatory general internists. The growth of hospitalists is thought to come at the expense of recruitment of residents to ambulatory general internal medicine. Hospital medicine is also believed to lure residents away from some internal medicine specialties. One of the driving forces is compensation, which is often greater than for ambulatory general internal medicine and comparable to some internal medicine specialty salaries, such as infectious disease. ${ }^{10}$ The membership survey reveals this discrepancy in academic medicine. Although half of all hospitalist respondents had an academic rank of instructor or assistant professor, financial compensation was comparable between the groups, which implies a higher salary among hospitalists independent of rank or experience. In other words, there was a statistically significant difference between hospitalists and non-hospitalists in academic rank, but no significant difference in salary. The exception was with salaries over $\$ 300,000$, which slightly favored the nonhospitalists. At the highest salaries, this reflects status in key leadership positions such as deans, chairs, and experienced division chiefs. As the senior hospitalist leadership in SGIM grows, this may change, especially with a large percentage of hospitalists taking on educational leadership roles. Nonetheless, while the compensation remains higher in hospital medicine, it will likely continue to promote its growth as a specialty. ${ }^{11}$ What role this plays in SGIM membership and resident choice of career is not clear, and is an opportunity for further study and future membership surveys.

Limitations of the study include recall and sampling bias. Both the hospitalist and non-hospitalist arms are subject to the same recall and sampling bias, which likely selected for respondents who tended to have a more favorable view of the society as a whole. Also, only $30.6 \%$ of SGIM members completed the survey, which raises concerns as to whether this is a representative sample, although it is comparable to 2012 and 2009 surveys.

\section{CONCLUSIONS}

Hospitalists are a growing constituency among the membership of SGIM. They are younger and earlier in their careers than most members. A smaller percentage of hospitalists identify SGIM as their professional home, and a smaller percentage consider SGIM essential. Nonetheless, the majority of hospitalists find SGIM a valuable organization and will continue membership. Opportunities still remain to reach out to hospitalists and strengthen ties by fostering interest in clinical teaching, clinical care, and opportunities for publication. Finally, this is a phenomenon that lends itself to further study and further exploration in future membership surveys.

Acknowledgements: We would like to acknowledge additional members of the SGIM Membership Committee in 2014 who contributed to the development of the Survey.

Irene Alexandraki, MD is at Florida State University, Tallahassee, FL, USA.

Marilyn Schapira, MD, MPH, University of Pennsylvania Department of Internal Medicine, Philadelphia, PA, USA.

Jeffrey C. Whittle, MD, MPH, Medical College of Wisconsin Department of Internal Medicine, Milwaukee, WI, USA.

Melissa Wei, MD, University of Michigan Department of Internal Medicine, Ann Arbor, MI, USA.

Corresponding Author: Chad S. Miller, MD; Department of Internal MedicineSaint Louis University, St. Louis, MO, USA (e-mail: chadmiller@slu.edu). 


\section{Compliance with Ethical Standards:}

Conflict of Interest: The authors declare that they do not have a conflict of interest.

\section{REFERENCES}

1. www.sgim.org. About us. 2016. Accessed 13 Oct 2016

2. Wachter RM, Goldman L. The emerging role of "hospitalists" in the American health care system. N Engl J Med. 1996;335:5147
3. Lurie JD, Miller DP, Lindenauer PK, Wachter RM, Sox HC. The potential size of the hospitalist workforce in the United States. Am J Med. 1999; 106:441-5.

4. Lapps J, Flansbaum B, Leykum L, Boswell J, Haines L. Updating threshold-based identification of hospitalists in 2012 Medicare pay data. J Hosp Med. 2016;11:45-7.

5. About the Society of Hospital Medicine. Society of Hospital Medicine, 2017. Accessed 2 June 2017, http://www.hospitalmedicine.org/Web/ About/SHM, 2017.

6. Amin AN. The hospitalist model of care: a positive influence on efficiency, quality of care, and outcomes. Crit Pathw Cardiol. 2004;3:S5-7.

7. Freed DH. Hospitalists: Evolution, Evidence, and Eventualities. Health Care Manag. 2004;23:238-56.

8. Wachter RM. Reflections: the hospitalist movement a decade later. J Hosp Med. 2006;1:248-52. 